
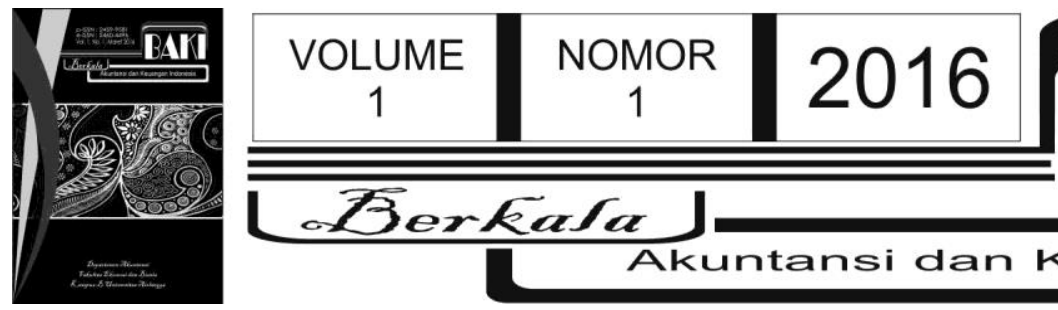

Berkata

Akuntansi dan Keuangan Indonesia

\title{
Analisis Pengembangan Corporate Value berdasarkan Keputusan Investasi dan Pendanaan, Struktur Kepemilikan serta Kebijakan Dividen pada Perusahaan Manufaktur yang Terdaftar di Bursa Efek Indonesia
}

\author{
Verawaty*, Citra Indah Merina, Irra Kurniawati \\ *Universitas Bina Darma \\ *verawaty_mahyudin@yahoo.com
}

I N F O ARTIKEL

\begin{tabular}{l}
\hline Histori Artikel: \\
Tanggal Masuk 19 November 2015 \\
Tanggal Diterima 25 Februari 2016 \\
Tersedia Online 31 Maret 2016 \\
\hline Kata Kunci: \\
nilai perusahaan; \\
keputusan investasi; \\
keputusan pendanaan; \\
kebijakan deviden; \\
kepemilikan manajerial; \\
kepemilikan institusional
\end{tabular}

\begin{abstract}
A B S TRAK
Penelitian ini membahas variabel-variabel yang mempengaruhi pengembangan nilai perusahaan pada perusahaan manufaktur di Bursa Efek Indonesia. Sektor manufaktur dipilih sebagai objek penelitian karena sektor manufaktur berhubungan langsung dengan daya beli masyarakat sehari-hari dan perusahaan akan selalu berproduksi serta membutuhkan keputusan dan kebijakan yang tepat dalam hal pengalokasian keuangan perusahaan, sehingga pengembangan nilai perusahaan pada perusahaan manufaktur lebih terlihat dan menjadi daya tarik serta pertimbangan bagi investor yang ingin berinvestasi di perusahaan manufaktur. Variabel-variabel yang akan dianalisis adalah keputusan investasi, keputusan pendanaan, kepemilikan manajerial dan kepemilikan institusional, serta kebijakan dividen. Populasi penelitian ini adalah 138 perusahaan manufaktur Indonesia Stock Exchange (IDX) Fact Book 2013. Hasil pengujian hipotesis menunjukkan bahwa variabel keputusan investasi, kepemilikan manajerial, dan kepemilikan institusional memiliki pengaruh signifikan terhadap nilai perusahaan. Adapun variabel keputusan pendanaan dan kebijakan dividen tidak memiliki pengaruh signifikan terhadap nilai perusahaan.
\end{abstract}

\section{Pendahuluan}

Persaingan usaha yang semakin ketat mendorong perusahaan untuk mampu bersaing guna meningkatkan nilai perusahaan. Persaingan bisnis di Indonesia saat ini telah menunjukkan kemajuan yang pesat dengan semakin bertambahnya jumlah perusahaan dari hari ke hari. Berbagai jenis perusahaan bermunculan yang bergerak di bidang yang berbeda-beda seperti bidang jasa, manufaktur, ataupun dagang yang saling bersaing untuk dapat bertahan dan menjadi yang terbaik. Apalagi saat ini, Indonesia dihadapkan pada serangkaian tantangan yang cukup kompleks. Salah satu tantangan yang ada adalah AEC (ASEAN Economic Community) yang diberlakukan mulai tahun 2015. AEC adalah kesepakatan antar negara-negara ASEAN di bidang tenaga kerja. Hal ini juga 
berdampak terhadap perekonomian pasar modal yang menjalankan perspektif keterbukaan dan daya saing sektor pasar modal Indonesia sehingga mendorong masing-masing perusahaan untuk melakukan berbagai strategi agar terhindar dari kebangkrutan.

Banyak strategi yang dilakukan oleh perusahaan untuk mempertahankan eksistensi perusahaan, baik dalam hal investasi, kualitas perusahaan, nilai perusahaan dan banyak lagi lainnya. Perusahaan yang baik dapat dilihat dari seberapa banyak investor yang berinvestasi, pengelolaan dana yang dilakukan manajemen keuangan dalam operasional perusahaan, peran atau kebijakan struktur kepemilikan baik manajerial ataupun institusi, dan pembagian atau penahanan dividen kepada pemegang saham.

Perusahaan mempunyai tujuan jangka panjang yaitu memaksimumkan nilai perusahaan. Namun, tidak jarang pihak manajemen mempunyai tujuan lain yang mungkin bertentangan dengan tujuan utama tersebut. Semakin tinggi nilai perusahaan maka kemakmuran pemegang saham akan semakin meningkat. Pemegang saham, kreditor dan manajer adalah pihak-pihak yang memiliki perbedaan kepentingan dan perspektif berkenaan dengan perusahaan. Pemegang saham akan cenderung memaksimalkan nilai saham dan memaksa manajer untuk bertindak sesuai dengan kepentingan mereka melalui pengawasan yang mereka lakukan. Kreditor di sisi lain cenderung akan berusaha melindungi dana yang sudah mereka investasikan dalam perusahaan dengan jaminan dan kebijakan pengawasan yang ketat pula. Manajer juga memiliki dorongan untuk mengejar kepentingan pribadi mereka. Bahkan tidak tertutup kemungkinan para manajer melakukan investasi walaupun investasi tersebut tidak dapat memaksimalkan nilai pemegang saham (Arieska dan Gunawan 2011).

Manajer harus mampu menghimpun dana, baik yang bersumber dari dalam perusahaan maupun luar perusahaan secara efisien dan efektif. Pada prinsipnya setiap perusahaan membutuhkan modal untuk melaksanakan kegiatannya, baik untuk memenuhi kebutuhan investasi jangka panjang maupun kegiatan operasional sehari-hari perusahaannya, karena modal merupakan alat yang sangat vital bagi kelancaran kegiatan operasional suatu perusahaan. Besarnya modal yang dibutuhkan akan berbeda sesuai dengan besar kecilnya perusahaan. Semakin besar suatu perusahaan, maka dana yang dibutuhkan semakin banyak.

Pasar modal Indonesia yang dikategorikan sebagai pasar modal yang sedang tumbuh memiliki potensi yang tinggi untuk memberi kontribusi dalam ekonomi Indonesia. Bursa Efek Indonesia menjadi acuan pasar modal di Indonesia, seperti diketahui bahwa krisis ekonomi Indonesia berdampak pada nilai fundamental perusahaan, khususnya perusahaan yang listing di pasar modal. Nilai perusahaan akan tercermin dari harga sahamnya (Wahyudi dan Pawestri 2006). Harga saham di pasar modal terbentuk berdasarkan kesepakatan antara permintaan dan penawaran investor, sehingga harga saham merupakan fair price yang dapat dijadikan sebagai proksi nilai perusahaan. Bila harga saham meningkat berarti nilai perusahaan meningkat (Hermuningsih dan Wardani, 2009).

Ada beberapa hal yang bisa mempengaruhi pengembangan nilai perusahaan (corporate value), diantaranya keputusan investasi, keputusan pendanaan, struktur kepemilikan yang terdiri dari kepemilikan manajerial dan kepemilikan instiusional, serta kebijakan dividen. Kelima hal yang 
mempengaruhi nilai perusahaan tersebut, merupakan keputusan keuangan suatu perusahaan yang saling berkaikatan satu dengan yang lainnya dalam memaksimumkan nilai perusahaan.

Menurut Hidayat (2010), keputusan investasi merupakan faktor penting dalam fungsi keuangan perusahaan, dimana nilai perusahaan semata-mata ditentukan oleh keputusan investasi. Pendapat tersebut dapat diartikan bahwa keputusan investasi itu penting, karena untuk mencapai tujuan perusahaan yaitu memaksimumkan kemakmuran pemegang saham hanya akan dihasilkan melalui kegiatan investasi perusahaan. Tujuan dilakukannya keputusan investasi adalah mendapat laba yang besar dengan risiko yang dapat dikelola dengan harapan dapat mengoptimalkan nilai perusahaan, yang berarti menaikkan kemakmuran pemegang saham (Afzal dan Rohman, 2012). Dengan demikian semakin tinggi keuntungan perusahaan semakin tinggi nilai perusahaan, yang berarti semakin besar kemakmuran yang akan diterima oleh pemilik perusahaan.

Keputusan pendanaan didefinisikan sebagai keputusan yang menyangkut komposisi pendanaan yang dipilih oleh perusahaan (Darminto 2010). Sudana (2011) menyatakan, keputusan pendanaan berkaitan dengan proses pemilihan sumber dana yang dipakai untuk membelanjai investasi yang direncanakan dengan berbagai alternatif sumber dana yang tersedia, sehingga diperoleh suatu kombinasi pembelanjaan yang paling efektif. Alternatif pendanaan yang dilakukan oleh perusahaan dapat berasal dari beberapa sumber, hutang (kewajiban-kewajiban) dan ekuitas. Hutang adalah uang yang telah dipinjam dan harus dibayar kembali pada tanggal yang telah ditentukan. Ekuitas, disisi lain, menunjukkan investasi pemegang saham dalam perusahaan. Sumber pendanaan tersebut dapat berasal dari internal perusahaan maupun dari eksternal perusahaan. Menurut Hasnawati (2005), proporsi penggunaan sumber dana internal atau eksternal dalam memenuhi kebutuhan dana perusahaan menjadi sangat penting dalam manajemen keuangan perusahaan. Bauran yang optimal akan menyumbangkan benefit dan cost, sehingga akan meminimalkan biaya modal dan meningkatkan nilai perusahaan (Darminto 2010). Dengan demikian, hal ini yang menjadi bahan pertimbangan nilai perusahaan, karena dengan keputusan pendanaan yang baik dan benar, maka akan menghasilkan nilai perusahaan yang baik juga.

Kepemilikan saham manajemen adalah proporsi saham biasa yang dimiliki oleh para manajemen (Suranta dan Midiastuty 2003). Siallagan dan Machfoedz (2006) menyatakan, semakin besar kepemilikan manjemen dalam perusahaan maka manajemen akan cenderung untuk berusaha meningkatkan kinerjanya untuk kepentingan pemegang saham dan untuk kepentingannya sendiri. Adanya kepemilikan manajemen akan menimbulkan suatu pengawasan terhadap kebijakankebijakan yang akan diambil oleh manajemen perusahaan. Menurut Wahyudi dan Pawestri (2006), hubungan antara kepemilikan manajerial dengan nilai perusahaan adalah hubungan non monotonic yang muncul karena adanya insentif yang dimiliki oleh manajer dan mereka berusaha melakukan pensejajaran kepentingan dengan outsider ownership. Dengan demikian, kepemilikan saham oleh manajerial diharapkan manajer akan bertindak sesuai dengan keinginan para principal karena manajer akan termotivasi untuk meningkatkan kinerja dan nantinya dapat meningkatkan nilai perusahaan. 
Kepemilikan institusional adalah proporsi kepemilikan saham pada akhir tahun yang dimiliki oleh lembaga, seperti asuransi, bank atau institusi lainnya (Tarjo 2008). Kepemilikan institusional memiliki arti penting dalam memonitor manajemen. Adanya kepemilikan oleh institusional akan mendorong peningkatan pengawasan yang lebih optimal. Tingginya kepemilikan oleh institusi akan meningkatkan pengawasan terhadap perusahaan. Pengawasan yang tinggi ini akan meminimalisasi tingkat penyelewengan-penyelewengan yang dilakukan oleh pihak manajemen yang akan menurunkan nilai perusahaan. Selain itu, pemilik institusional akan berusaha melakukan usaha-usaha positif guna meningkatkan nilai perusahaan miliknya. Semakin tinggi kepemilikan institusional maka akan mengurangi perilaku opportunistic manager yang diharapkan akan meningkatkan nilai perusahaan (Wahyudi dan Pawestri 2006). Dengan demikian, semakin tinggi kepemilikan institusional, maka nilai perusahaan akan semakin tinggi.

Menurut Mandagi (2010), kebijakan dividen menentukan berapa banyak laba yang harus dibayar kepada pemegang saham dan berapa banyak yang harus ditanam kembali di dalam perusahaan (laba ditahan). Laba ditahan merupakan salah satu sumber dana internal. Menurut Gayatri dan Mustanda (2013), kekhawatiran yang dihadapi oleh perusahaan dalam kebijakan dividen adalah seberapa banyak pendapatan yang bisa dibayarkan sebagai dividen dan seberapa banyak dapat dipertahankan, karena terkadang pembagian dividen bagi sebagian investor bukanlah sinyal positif. Investor menganggap manajer perusahaan tidak peka pada peluang investasi yang akan mendatangkan keuntungan namun lebih memilih membagikan dividen sehingga, nilai perusahaan dapat turun karena kurangnya keinginan pemegang saham untuk menanamkan modalnya pada perusahaan tersebut. Kemampuan perusahaan dalam membayarkan dividen dapat mencerminkan nilai perusahaan (Gayatri dan Mustanda 2013). Dengan demikian, jika pembayaran dividen tinggi, maka harga saham juga tinggi yang berdampak pada tingginya nilai perusahaan begitu juga sebaliknya.

Penelitian ini merupakan pengembangan dari penelitian yang dilakukan Ningsih dan Indarti (2011), tetapi terdapat perbedaan dengan penelitian tersebut ataupun penelitian sebelumnya. Penelitian yang dilakukan Ningsih dan Indarti (2011) menyarankan untuk menambahkan variabel struktur kepemilikan untuk mengetahui pengaruh dari struktur kepemilikan terhadap pengembangan nilai perusahaan. Struktur kepemilikan terbagi menjadi dua jenis, kepemilikan manajerial dan kepemilikan institusional.

Peneliti menambahkan variabel kepemilikan manajerial dan kepemilikan institusional, karena kedua variabel itu juga mempengaruhi keputusan keuangan yang akan berdampak terhadap tujuan perusahaan untuk meningkatkan nilai perusahaan. Kepemilikan saham oleh manajerial akan memotivasi manajer untuk meningkatkan kinerja dan nantinya dapat meningkatkan nilai perusahaan. Hal ini berarti, semakin tinggi kepemilikan institusional, maka nilai perusahaan akan semakin tinggi. Penjelasan di atas didukung dengan penelitian Endraswati (2009) yang menyatakan kepemilikan manajerial dan kepemilikan institusional berpengaruh terhadap nilai perusahaan. Menurut Permanasari (2010), kepemilikan manajerial dan kepemilikan institusional tidak berpengaruh 
terhadap nilai perusahaan. Selain mengembangkan penelitian yang dilakukan Ningsih dan Indarti (2010), ketidakkonsistenan hasil penelitian terdahulu yang dilakukan Permanasari (2010) dan Endraswati (2009) juga melatarbelakangi penelitian ini.

Pada penelitian ini, sektor manufaktur dipilih sebagai objek penelitian karena sektor manufaktur merupakan salah satu perusahaan dengan jumlah emiten terbanyak di Bursa Efek Indonesia dan merupakan perusahaan yang di dalamnya terjadi proses pengolahan bahan mentah menjadi barang jadi. Selain itu perusahaan manufaktur juga berhubungan langsung dengan daya beli masyarakat sehari-hari dan perusahaan akan selalu berproduksi serta membutuhkan keputusan dan kebijakan yang tepat dalam hal pengalokasian keuangan perusahaan, sehingga pengembangan nilai perusahaan (corporate value) pada perusahaan manufaktur lebih terlihat dan menjadi daya tarik serta pertimbangan bagi investor yang ingin berinvestasi di perusahaan manufaktur.

Penelitian ini membahas variabel-variabel yang mempengaruhi pengembangan nilai perusahaan pada perusahaan manufaktur di Bursa Efek Indonesia. Variabel-variabel yang akan dianalisis adalah keputusan investasi, keputusan pendanaan, kepemilikan manajerial dan kepemilikan institusional, serta kebijakan dividen. Peneliti menguji apakah terdapat hubungan positif antara kelima variabel tersebut terhadap nilai perusahaan. Tujuan penelitian ini untuk menganalisis pengaruh keputusan investasi dan pendanaan, struktur kepemilikan yang terdiri dari kepemilikan manjerial dan kepemilikan institusional serta kebijakan dividen terhadap pengembangan nilai perusahaan.

\section{Tinjauan Pustaka}

\subsection{Teori - Teori yang Digunakan}

\subsubsection{Teori Keagenan (Agency Theory)}

Teori keagenan atau agency theory dikemukakan oleh Michael C. Jensen dan William H. Meckling pada tahun 1976. Jensen dan Meckling (1976) menggambarkan hubungan agency sebagai suatu kontrak di bawah satu atau lebih (principal) yang melibatkan orang lain (agent) untuk melaksanakan beberapa layanan bagi mereka dengan melibatkan pendelegasian wewenang pengambilan keputusan kepada agen. Teori keagenan merupakan basis teori yang mendasari praktek bisnis perusahaan yang dipakai selama ini. Prinsip utama teori ini menyatakan adanya hubungan kerja antara pihak yang memberi wewenang (prinsipal) dengan yang menerima wewenang (agen). Dengan demikian, inti dari hubungan keagenan adalah terdapat pemisahan antara kepemilikan dan pengelolaan perusahaan. Agency theory menjelaskan adanya benturan kepentingan antara prinsipal dan agen.

Pada teori keagenan yang disebut prinsipal adalah pemegang saham dan yang disebut agen adalah manajemen yang mengelola perusahaan. Prinsipal diasumsikan hanya tertarik pada pengembalian keuangan yang diperoleh dari investasi mereka pada perusahaan, sedangkan agen diasumsikan akan menerima kepuasan tidak hanya dari kompensasi keuangan tetapi juga dari tambahan lain yang terlibat dalam hubungan keagenan (Anthony dan Govindarajan 2005). 
Tujuan utama perusahaan adalah memaksimalkan kemakmuran pemegang saham. Pihak manajemen diharapkan bertindak dan mengambil keputusan untuk kepentingan pemegang saham. Namun, dalam praktiknya sering terjadi konflik antara pihak manajemen dengan pemegang saham. Konflik tersebut terjadi pada saat proporsi kepemilikan manajer atas saham perusahaan kurang dari $100 \%$ sehingga manajer cenderung mengutamakan kepentingan pribadi dan tidak berdasarkan pada tujuan perusahaan yaitu memaksimalkan nilai perusahaan dalam pengambilan keputusan keuangan khususnya keputusan pendanaan (Bestivano 2013).

Bestivano (2013) menggunakan asumsi sifat dasar manusia untuk menjelaskan tentang teori agensi, yaitu manusia pada umumnya mementingkan diri sendiri (self interest), manusia memiliki daya pikir terbatas mengenai persepsi masa mendatang (bounded rationality), dan manusia selalu menghindari resiko (risk adverse). Salah satu sifat dasar manusia adalah self interest artinya mementingkan diri sendiri dan tidak mau berkorban untuk orang lain. Sesuai dengan asumsi tersebut, maka manajer akan mengambil kebijakan yang menguntungkan dirinya sebelum memberikan manfaat kepada pemegang saham.

Jika dikaitkan dengan penelitian ini, teori agensi berperan dan mendasari praktek bisnis perusahaan yang akan meningkatkan nilai perusahaan dengan memaksimalkan kemakmuran pemegang saham. Ketika pengambilan keputusan keuangan, teori agensi berperan pada kepemilikan manajerial yang lebih mengutamakan kepentingan pribadi bukan kepentingan pemegang saham atau kepemilikan institusional.

\subsubsection{Teori Sinyal (Signalling Theory)}

Teori sinyal mengemukakan tentang bagaimana seharusnya sebuah perusahaan memberikan sinyal kepada pengguna laporan keuangan. Brigham dan Houston (2001) dalam Fenandar (2012) menyatakan bahwa sinyal adalah suatu tindakan yang diambil oleh manajemen perusahaan yang memberikan petunjuk bagi investor tentang bagaimana manajemen memandang prospek perusahaan. Perusahaan dengan prospek yang menguntungkan akan mencoba menghindari penjualan saham dan mengusahakan modal baru dengan cara-cara lain seperti dengan menggunakan hutang.

Wahyudi dan Pawestri (2006) menyatakan bahwa pengeluaran investasi memberikan sinyal positif tentang pertumbuhan perusahaan di masa mendatang, sehingga dapat meningkatkan harga saham yang digunakan sebagai indikator nilai perusahaan. Peningkatan utang diartikan oleh pihak luar sebagai kemampuan perusahaan untuk membayar kewajiban di masa mendatang atau adanya risiko bisnis yang rendah, dimana hal tersebut direspon positif oleh pasar (Brigham dan Houston (2001) dalam Fenandar 2012).

Menurut Wahyudi dan Pawestri (2006), dividen mengandung informasi atau digunakan sebagai isyarat atau sinyal akan prospek perusahaan. Hal ini menunjukkan bahwa peningkatan dividen yang dibagikan kepada pemegang saham akan memberikan sinyal positif mengenai kinerja perusahaan, sehingga dapat menarik para investor. 
Teori sinyal (signalling theory) merupakan teori yang menjelaskan persepsi investor luar tentang prospek perusahaan akibat adanya corporate action (Hasnawati 2005). Teori sinyal menjelaskan mengapa perusahaan mempunyai dorongan untuk memberikan informasi laporan keuangan pada pihak eksternal. Dorongan perusahaan untuk memberikan informasi karena terdapat asimetri informasi antara perusahaan dan pihak luar karena perusahaan mengetahui lebih banyak mengenai perusahaan dan prospek yang akan datang dari pada pihak luar (investor dan kreditor). Kurangnya informasi bagi pihak luar mengenai perusahaan menyebabkan mereka melindungi diri mereka dengan memberikan harga yang rendah untuk perusahaan. Perusahaan dapat meningkatkan nilai perusahaan dengan mengurangi informasi asimetri. Salah satu cara untuk mengurangi informasi asimetri adalah dengan memberikan sinyal pada pihak luar, salah satunya berupa informasi keuangan yang dapat dipercaya dan akan mengurangi ketidakpastian mengenai prospek perusahaan yang akan datang. Dengan demikian, teori ini mendukung pengembangan nilai perusahaan dengan memberikan petunjuk bagi investor mengenai prospek perusahaan. Semakin jelas informasi keuangan yang diberikan perusahaan, maka semakin mudah untuk menarik perhatian para investor. Investor bisa menilai perusahaan dari informasi keuangan perusahaan dan aktivitas perusahaan.

\subsection{Penelitian-Penelitian Terdahulu dan Pengembangan Hipotesis}

Penelitian yang berkaitan dengan nilai perusahaan telah banyak dilakukan. Terutama kebijakan dan keputusan apa saja yang mempengaruhi nilai perusahaan (Corporate Value). Kebijakan dan keputusan yang sering digunakan adalah keputusan investasi, keputusan pendanaan, dan kebijakan dividen. Diantaranya dilakukan oleh Darminto (2010), Wijaya et al. (2010), dan Ningsih dan Indarti (2011).

Penelitian ini merupakan pengembangan dari penelitian yang dilakukan Ningsih dan Indarti (2011), tetapi terdapat perbedaan dengan penelitian tersebut ataupun penelitian sebelumnya. Penelitian yang dilakukan Ningsih dan Indarti (2011) menyarankan untuk menambahkan variabel struktur kepemilikan untuk mengetahui pengaruh dari struktur kepemilikan terhadap pengembangan nilai perusahaan. Struktur kepemilikan terbagi menjadi dua jenis, kepemilikan manajerial dan kepemilikan institusional.

Peneliti menambahkan variabel kepemilikan manajerial dan kepemilikan institusional, karena kedua variabel itu juga mempengaruhi keputusan keuangan yang akan berdampak terhadap tujuan perusahaan untuk meningkatkan nilai perusahaan. Kepemilikan saham oleh manajerial akan memotivasi manajer untuk meningkatkan kinerja dan nantinya dapat meningkatkan nilai perusahaan. Hal ini berarti bahwa semakin tinggi kepemilikan institusional, maka nilai perusahaan akan semakin tinggi. Penjelasan di atas didukung dengan penelitian Endraswati (2009) yang menyatakan kepemilikan manajerial dan kepemilikan institusional berpengaruh terhadap nilai perusahaan. Menurut Permanasari (2010), kepemilikan manajerial dan kepemilikan institusional tidak berpengaruh terhadap nilai perusahaan. Selain mengembangkan penelitian yang dilakukan Ningsih dan Indarti 
(2010), ketidakkonsistenan hasil penelitian terdahulu yang dilakukan Endraswati (2009) dan Permanasari (2010) juga melatarbelakangi penelitian ini.

\subsubsection{Pengaruh Keputusan Investasi Terhadap Nilai Perusahaan}

Keputusan investasi merupakan faktor penting dalam fungsi keuangan perusahaan, dimana nilai perusahaan semata-mata ditentukan oleh keputusan investasi (Hidayat 2010). Pendapat tersebut dapat diartikan bahwa keputusan investasi itu penting, karena untuk mencapai tujuan perusahaan yaitu memaksimumkan kemakmuran pemegang saham hanya akan dihasilkan melalui kegiatan investasi perusahaan. Tujuan dilakukannya keputusan investasi adalah mendapat laba yang besar dengan risiko yang dapat dikelola dengan harapan dapat mengoptimalkan nilai perusahaan, yang berarti menaikkan kemakmuran pemegang saham (Afzal dan Rohman 2012). Dengan demikian semakin tinggi keuntungan perusahaan semakin tinggi nilai perusahaan, yang berarti semakin besar kemakmuran yang akan diterima oleh pemilik perusahaan.

Penelitian yang dilakukan oleh Darminto (2010), Wijaya et al. (2010), Ningsih dan Indarti (2011), Mandagi (2010), dan Afzal dan Rohman (2012) menyatakan bahwa keputusan investasi berpengaruh terhadap nilai perusahaan, sedangkan penelitian yang dilakukan Wahyudi dan Pawestri (2006) menyatakan tidak berpengaruh terhadap nilai perusahaan. Dari beberapa penelitian terdahulu, masih adanya temuan hasil penelitian yang tidak konsisten sehingga peneliti perlu melakukan pengujian kembali untuk mengetahui konsistensi temuan penelitian keputusan investasi terhadap nilai perusahaan ke dalam hipotesis sebagai berikut:

H1: Keputusan investasi berpengaruh positif terhadap nilai perusahaan.

\subsubsection{Pengaruh Keputusan Pendanaan Terhadap Nilai Perusahaan}

Keputusan pendanaan didefinisikan sebagai keputusan yang menyangkut komposisi pendanaan yang dipilih oleh perusahaan (Darminto 2010). Sudana (2011) menyatakan keputusan pendanaan berkaitan dengan proses pemilihan sumber dana yang dipakai untuk membelanjai investasi yang direncanakan dengan berbagai alternatif sumber dana yang tersedia, sehingga diperoleh suatu kombinasi pembelanjaan yang paling efektif. Alternatif pendanaan yang dilakukan oleh perusahaan dapat berasal dari beberapa sumber, hutang (kewajiban-kewajiban) dan ekuitas. Hutang adalah uang yang telah dipinjam dan harus dibayar kembali pada tanggal yang telah ditentukan. Ekuitas, di sisi lain, menunjukkan investasi pemegang saham dalam perusahaan. Sumber pendanaan tersebut dapat berasal dari internal perusahaan maupun dari eksternal perusahaan. Menurut Hasnawati (2005), proporsi penggunaan sumber dana internal atau eksternal dalam memenuhi kebutuhan dana perusahaan menjadi sangat penting dalam manajemen keuangan perusahaan. Bauran yang optimal akan menyumbangkan benefit dan cost, sehingga akan meminimalkan biaya modal dan meningkatkan nilai perusahaan (Darminto 2010). Dengan demikian, hal ini yang menjadi bahan 
pertimbangan nilai perusahaan, karena dengan keputusan pendanaan yang baik dan benar, maka akan menghasilkan nilai perusahaan yang baik juga.

Penelitian Darminto (2010), Wijaya et al. (2010), Ningsih dan Indarti (2011), dan Afzal dan Rohman (2012) menyatakan bahwa keputusan pendanaan berpengaruh positif terhadap nilai perusahaan, sedangkan penelitian yang dilakukan Mandagi (2010) menyatakan tidak berpengaruh positif terhadap nilai perusahaan. Dari beberapa penelitian terdahulu, masih adanya temuan hasil penelitian yang tidak konsisten sehingga peneliti perlu melakukan pengujian kembali untuk mengetahui konsistensi temuan penelitian keputusan pendanaan terhadap nilai perusahaan ke dalam hipotesis sebagai berikut:

H2: Keputusan pendanaan berpengaruh positif terhadap nilai perusahaan.

\subsubsection{Pengaruh Kepemilikan Manajerial Terhadap Nilai Perusahaan}

Kepemilikan saham manajemen adalah proporsi saham biasa yang dimiliki oleh para manajemen. Siallagan dan Machfoedz (2006) menyatakan, semakin besar kepemilikan manajemen dalam perusahaan maka manajemen akan cenderung untuk berusaha meningkatkan kinerjanya untuk kepentingan pemegang saham dan untuk kepentingannya sendiri. Adanya kepemilikan manajemen akan menimbulkan suatu pengawasan terhadap kebijakan-kebijakan yang akan diambil oleh manajemen perusahaan. Menurut Wahyudi dan Pawestri (2006), hubungan antara kepemilikan manajerial dengan nilai perusahaan adalah hubungan non monotonic yang muncul karena adanya insentif yang dimiliki oleh manajer dan mereka berusaha melakukan pensejajaran kepentingan dengan outsider ownership. Dengan demikian, kepemilikan saham oleh manajerial diharapkan manajer akan bertindak sesuai dengan keinginan para principal karena manajer akan termotivasi untuk meningkatkan kinerja dan nantinya dapat meningkatkan nilai perusahaan.

Penelitian Wahyudi dan Pawestri (2006), Endraswati (2009), dan Sukirni (2012) menyatakan bahwa kepemilikan manajerial berpengaruh positif terhadap nilai perusahaan, sedangkan penelitian yang dilakukan Sujoko dan Soebiantoro (2007) dan Permanasari (2010) menyatakan tidak berpengaruh positif terhadap nilai perusahaan. Dari beberapa penelitian terdahulu, masih adanya temuan hasil penelitian yang tidak konsisten sehingga peneliti perlu melakukan pengujian kembali untuk mengetahui konsistensi temuan penelitian kepemilikan manajerial terhadap nilai perusahaan ke dalam hipotesis sebagai berikut:

H3: Kepemilikan manajerial berpengaruh positif terhadap nilai perusahaan.

\subsubsection{Pengaruh Kepemilikan Institusional Terhadap Nilai Perusahaan}

Kepemilikan institusional adalah proporsi kepemilikan saham pada akhir tahun yang dimiliki oleh lembaga, seperti asuransi, bank atau institusi lainnya (Tarjo 2008). Kepemilikan institusional memiliki arti penting dalam memonitor manajemen. Adanya kepemilikan oleh institusional akan mendorong peningkatan pengawasan yang lebih optimal. Semakin tinggi kepemilikan institusional maka akan 
mengurangi perilaku opportunistic manager yang diharapkan akan meningkatkan nilai perusahaan (Wahyudi dan Pawestri 2006). Tingginya kepemilikan oleh institusi akan meningkatkan pengawasan terhadap perusahaan. Pengawasan yang tinggi ini akan meminimalisasi tingkat penyelewenganpenyelewengan yang dilakukan oleh pihak manajemen yang akan menurunkan nilai perusahaan. Selain itu, pemilik institusional akan berusaha melakukan usaha-usaha positif guna meningkatkan nilai perusahaan miliknya. Dengan demikian, semakin tinggi kepemilikan institusional, maka nilai perusahaan akan semakin tinggi.

Penelitian Sujoko dan Soebiantoro (2007), Endraswati (2009), dan Sukirni (2012) menyatakan bahwa kepemilikan Institusional berpengaruh positif terhadap nilai perusahaan, sedangkan penelitian yang dilakukan Wahyudi dan Pawestri (2006) dan Permanasari (2010) menyatakan tidak berpengaruh positif terhadap nilai perusahaan. Dari beberapa penelitian terdahulu, masih adanya temuan hasil penelitian yang tidak konsisten sehingga peneliti perlu melakukan pengujian kembali untuk mengetahui konsistensi temuan penelitian kepemilikan institusional terhadap nilai perusahaan ke dalam hipotesis sebagai berikut:

H4: Kepemilikan institusional berpengaruh positif terhadap nilai perusahaan.

\subsubsection{Pengaruh Kebijakan Dividen terhadap Nilai Perusahaan}

Menurut Mandagi (2010), kebijakan dividen menentukan berapa banyak laba yang harus dibayar kepada pemegang saham dan berapa banyak yang harus ditanam kembali di dalam perusahaan (laba ditahan). Laba ditahan merupakan salah satu sumber dana internal. Menurut Gayatri dan Mustanda (2013), kekhawatiran yang dihadapi oleh perusahaan dalam kebijakan dividen adalah seberapa banyak pendapatan yang bisa dibayarkan sebagai dividen dan seberapa banyak dapat dipertahankan, karena terkadang pembagian dividen bagi sebagian investor bukanlah sinyal positif. Investor menganggap manajer perusahaan tidak peka pada peluang investasi yang akan mendatangkan keuntungan namun lebih memilih membagikan dividen sehingga, nilai perusahaan dapat turun karena kurangnya keinginan pemegang saham untuk menanamkan modalnya pada perusahaan tersebut. Kemampuan perusahaan dalam membayarkan dividen dapat mencerminkan nilai perusahaan (Gayatri dan Mustanda 2013). Dengan demikian, jika pembayaran dividen tinggi, maka harga saham juga tinggi yang berdampak pada tingginya nilai perusahaan begitu juga sebaliknya.

Penelitian Darminto (2010), dan Wijaya et al. (2010) menyatakan berpengaruh positif terhadap nilai perusahaan, sedangkan penelitian Wahyudi dan Pawestri (2006), Endraswati (2009), dan Mandagi (2010) menyatakan tidak berpengaruh positif terhadap nilai perusahaan. Dari beberapa penelitian terdahulu, masih adanya temuan hasil penelitian yang tidak konsisten sehingga peneliti perlu melakukan pengujian kembali untuk mengetahui konsistensi temuan penelitian kebijakan dividen terhadap nilai perusahaan ke dalam hipotesis:

H5: Kebijakan dividen berpengaruh positif terhadap nilai perusahaan. 


\section{Metodologi Penelitian}

\subsection{Operasional Variabel}

\begin{tabular}{|c|c|c|c|}
\hline Variabel & Definisi Operasional & Indikator & Skala Ukur \\
\hline $\begin{array}{l}\text { Variabel Independen: } \\
\text { 1. Keputusan } \\
\text { Investasi }\end{array}$ & $\begin{array}{l}\text { Menurut Hidayat (2010), keputusan investasi } \\
\text { merupakan faktor penting dalam fungsi } \\
\text { keuangan perusahaan, dimana nilai perusahaan } \\
\text { semata-mata ditentukan oleh keputusan } \\
\text { investasi. }\end{array}$ & $\begin{array}{l}\text {-EPS } \\
\text {-harga saham } \\
\text {-laba per lembar } \\
\text { saham }\end{array}$ & Rasio \\
\hline $\begin{array}{ll}\text { 2. } & \text { Keputusan } \\
& \text { Pendanaan }\end{array}$ & $\begin{array}{l}\text { Keputusan pendanaan didefinisikan sebagai } \\
\text { keputusan yang menyangkut komposisi } \\
\text { pendanaan yang dipilih oleh perusahaan } \\
\text { (Darminto 2010). }\end{array}$ & $\begin{array}{l}\text {-DER } \\
\text {-Total Hutang } \\
\text {-Total Ekuitas }\end{array}$ & Rasio \\
\hline $\begin{array}{l}\text { 3. Struktur } \\
\text { Kepemilikan } \\
\text { (Kepemilikan } \\
\text { Manajerial) }\end{array}$ & $\begin{array}{l}\text { Kepemilikan saham manajemen adalah proporsi } \\
\text { saham biasa yang dimiliki oleh para manajemen } \\
\text { (Suranta dan Midiastuty, 2003). Siallagan dan } \\
\text { Machfoedz (2006) menyatakan, semakin besar } \\
\text { kepemilikan manajemen dalam perusahaan } \\
\text { maka manajemen akan cenderung untuk } \\
\text { berusaha meningkatkan kinerjanya untuk } \\
\text { kepentingan pemegang saham dan untuk } \\
\text { kepentingannya sendiri. }\end{array}$ & $\begin{array}{l}\text {-Jumlah lembar } \\
\text { saham yang } \\
\text { dimiliki } \\
\text { manajerial } \\
\text {-Jumlah saham } \\
\text { beredar }\end{array}$ & Rasio \\
\hline $\begin{array}{l}\text { 4. Struktur } \\
\text { Kepemilikan } \\
\text { (Kepemilikan } \\
\text { Institusional) }\end{array}$ & $\begin{array}{l}\text { Kepemilikan institusional merupakan persentase } \\
\text { saham yang dimiliki oleh investor institusional } \\
\text { seperti perusahaan asuransi, bank, perusahaan } \\
\text { investasi, dan kepemilikan institusi lain } \\
\text { (Novitasari 2011). }\end{array}$ & $\begin{array}{l}\text {-Jumlah saham } \\
\text { yang dimiliki } \\
\text { Institusional } \\
\text {-Jumlah saham } \\
\text { beredar }\end{array}$ & Rasio \\
\hline $\begin{array}{ll}\text { 5. } & \text { Kebijakan } \\
\text { Dividen }\end{array}$ & $\begin{array}{l}\text { Menurut Mandagi (2010), kebijakan dividen } \\
\text { menentukan berapa banyak laba yang harus } \\
\text { dibayar kepada pemegang saham dan berapa } \\
\text { banyak yang harus ditanam kembali di dalam } \\
\text { perusahaan (laba ditahan). }\end{array}$ & $\begin{array}{l}\text {-DPR } \\
\text {-Dividend Per } \\
\text { Share } \\
\text {-Earning Per } \\
\text { Share }\end{array}$ & Rasio \\
\hline $\begin{array}{l}\text { Variabel Dependen : } \\
\text { - Nilai } \\
\text { Perusahaan }\end{array}$ & $\begin{array}{l}\text { Nilai perusahaan adalah didefinisikan sebagai } \\
\text { nilai pasar karena nilai perusahaan dapat } \\
\text { memberikan kemakmuran pemegang saham } \\
\text { secara maksimum apabila harga saham } \\
\text { perusahaan meningkat (Wijaya dan Wibawa } \\
\text { 2010) }\end{array}$ & $\begin{array}{l}\text {-PBV } \\
\text {-Harga Saham } \\
\text {-Nilai Buku }\end{array}$ & Rasio \\
\hline
\end{tabular}

\subsection{Populasi dan Sampel}

Populasi dalam penelitian ini adalah perusahaan manufaktur yang listing di Bursa Efek Indonesia berdasarkan Indonesia Stock Exchange (IDX) Fact Book 2013. Metode pemilihan sampel pada penelitian ini ditentukan dengan metode purposive sampling yang bertujuan agar memperoleh sampel yang representatif (mewakili) sesuai dengan kriteria yang ditentukan. Adapun kriteria penentuan dalam sampel ini adalah sebagai berikut:

1. Perusahaan yang termasuk dalam kelompok industri manufaktur yang terdaftar di BEI dan mempublikasikan laporan keuangan tahun 2013 yang telah diaudit.

2. Perusahaan manufaktur yang selama tahun 2013 membagikan dividen.

3. Memiliki kepemilikan manajerial dan kepemilikan institusional.

4. Tersedia laporan keuangan perusahaan secara lengkap pada tahun 2013, baik secara fisik maupun melalui website. 


\subsection{Teknik Analisis}

Untuk menguji hipotesis, penelitian ini menggunakan analisis regresi linier berganda. Persamaan regresi yang digunakan dalam penelitian ini adalah:

$$
\mathrm{NP}=\alpha+\beta 1 \mathrm{KI}+\beta 2 \mathrm{KP}+\beta 3 \mathrm{KD}+\beta 4 \mathrm{KMM}+\beta 5 \mathrm{KMI}+\mathrm{e}
$$

\section{Keterangan:}

a : konstanta

B $\quad$ : koefisien regresi

NP : Nilai Perusahaan

$\mathrm{KI} \quad$ : Keputusan Investasi

KP : Keputusan Pendanaan

KD : Kebijakan Deviden

KMM : Kepemilikan Manajerial

KMI : Kepemilikan Institusional

E : koefisien eror

\section{Hasil dan Pembahasan}

\subsection{Hasil Penelitian}

Semua variabel penelitian telah lolos uji asumsi klasik. Hasil uji normalitas, yaitu nilai Kolmogorov-Smirnov (K-S) dan nilai Asymp. Sig. (2-tailed) dengan seluruh variabel di atas $\alpha=0,05$ yang berarti data yang diuji terdistribusi normal. Hasil uji multikolinearitas menyatakan nilai tolerance untuk seluruh variabel lebih besar dari 10\% dan VIF lebih kecil dari 10 yang berarti bahwa data penelitian ini tidak terjadi multikolinearitas. Hasil uji heteroskedastisitas menyatakan nilai signifikansi untuk setiap variabel bebas terhadap nilai absolute residual lebih besar dari 0,05 yang berarti bahwa tidak terjadi gejala heteroskedastisitas dalam penelitian ini.

\subsubsection{Uji Koefisien Determinasi $\left(R^{2}\right)$}

Tabel 4.1

Uji Koefisien Determinasi

\begin{tabular}{|l|l|l|}
\hline Model & R Square & Adjusted R Square \\
\hline 1 & .828 & .746 \\
\hline
\end{tabular}

Tabel 4.1 menunjukkan nilai adjusted $R^{2}$ sebesar 0,746 yang memiliki arti bahwa 74,6\% perubahan belanja modal dapat dijelaskan oleh variabel keputusan investasi, keputusan pendanaan, kepemilikan manajerial, kepemilikan institusional, dan kebijakan dividen sedangkan sisanya $25,4 \%$ dipengaruhi oleh variabel lain di luar model. 


\subsubsection{Uji Signifikansi Simultan (Uji F)}

Uji F atau uji hipotesis secara simultan digunakan untuk melihat apakah secara keseluruhan variabel bebas (independen) memiliki pengaruh secara bersama-sama terhadap variabel terikat (dependen). Dari pengujian hipotesis secara simultan diperoleh hasil yaitu sebagai berikut:

Tabel 4.2

Hasil Regresi Simultan

\begin{tabular}{|l|l|l|l|l|l|}
\hline \multicolumn{8}{|c|}{ ANOVA $^{\mathrm{b}}$} \\
\hline Model & Sum of Squares & Df & Mean Square & F & Sig. \\
\hline 1 Regression & 9.124 & 5 & 1.825 & 1.808 & $.155^{\mathrm{a}}$ \\
\hline Residual & 21.197 & 21 & 1.009 & & \\
\hline Total & 30.322 & 26 & & & \\
\hline
\end{tabular}

a. Predictors: (Constant), PER, DER, KMM, KMI, DPR

Berdasarkan hasil uji ANOVA atau $F$ test di atas, didapat $F$ hitung sebesar 1,808 dengan tingkat probabilitas 0,155 (tidak signifikan). Tabel 4.2 yaitu hasil uji $F$ (regresi simultan) juga menunjukkan bahwa nilai signifikan lebih besar dari tingkat signifikansi 0,05 , jadi dapat disimpulkan bahwa keputusan investasi, keputusan pendanaan, kepemilikan manajerial, kepemilikan institusional, dan kebijakan dividen tidak berpengaruh secara bersama terhadap corporate value (nilai perusahaan).

\subsubsection{Uji Signifikansi Parsial (Uji t)}

Uji t atau uji hipotesis secara parsial digunakan untuk mengetahui apakah secara parsial variabel bebas (independen) berpengaruh secara signifikan atau tidak terhadap variabel terikat (dependen). Dari pengujian hipotesis secara parsial diperoleh hasil yaitu sebagai berikut:

Tabel 4.3

Hasil Regresi Parsial

\begin{tabular}{|l|l|l|l|l|l|l|}
\hline \multicolumn{2}{|l}{} & \multicolumn{2}{l|}{$\begin{array}{l}\text { Unstandardized } \\
\text { Coefficients }\end{array}$} & $\begin{array}{l}\text { Standardized } \\
\text { Coefficients }\end{array}$ & & \\
\cline { 3 - 5 } Model & B & Std. Error & Beta & t & Sig. \\
\hline 1 & (Constant) & 35.782 & 16.346 & & 2.189 & .040 \\
\hline & PER & .506 & .253 & .443 & 1.995 & .059 \\
\hline & DER & -.315 & .262 & -.259 & -1.202 & .243 \\
\hline & KMM & -.288 & .111 & -.774 & -2.602 & .017 \\
\hline & KMI & -8.327 & 3.735 & -.665 & -2.230 & .037 \\
\hline & DPR & .188 & .174 & .258 & 1.079 & .293 \\
\hline
\end{tabular}

a. Dependent Variable: PBV

Berdasarkan hasil uji statistik t pada tabel 4.3, terlihat bahwa variabel kepemilikan manajerial (KMM) dan kepemilikan institusional (KMI) menunjukkan hubungan yang signifikan terhadap variabel dependen, yaitu nilai perusahaan (PBV) dengan tingkat signifikansi 5\%. Adapun keputusan investasi (PER) menunjukkan hubungan yang signifikan terhadap variabel dependen dengan tingkat signifikan $10 \%$. Hal ini dapat dilihat dari nilai probabilitas signifikan untuk kepemilikan manajerial dan kepemilikan institusional masing-masing sebesar 0,017 dan 0,037 (sig.<5\%), sedangkan nilai probabilitas signifikan untuk keputusan investasi sebesar 0,059 (sig. <10\%). 


\subsection{Pembahasan}

\subsubsection{Keputusan Investasi Berpengaruh Positif terhadap Nilai Perusahaan}

Hasil pengujian hipotesis pertama menunjukkan bahwa hipotesis pertama diterima. Hasil pengujian menunjukkan bahwa keputusan investasi memiliki pengaruh signifikan terhadap nilai perusahaan dengan nilai signifikansi 0,059 dimana nilai tersebut lebih kecil dari 0,1 ( $\alpha=10 \%)$. Hasil analisis ini tidak konsisten dengan hasil penelitian Wahyudi dan Pawestri (2006) yang menyatakan bahwa keputusan investasi tidak memiliki pengaruh terhadap nilai perusahaan. Akan tetapi, hasil analisis ini konsisten dengan hasil penelitian Darminto (2010), Wijaya et al. (2010), Ningsih dan Indarti (2011), Mandagi (2010), dan Afzal dan Rohman (2012) yang menyatakan bahwa keputusan investasi berpengaruh positif terhadap nilai perusahaan.

Keputusan investasi merupakan faktor penting dalam fungsi keuangan perusahaan. Hidayat (2010), menyatakan bahwa nilai perusahaan semata-mata ditentukan oleh keputusan investasi. Pendapat tersebut dapat diartikan bahwa keputusan investasi itu penting, karena untuk mencapai tujuan perusahaan yaitu memaksimumkan kemakmuran pemegang saham hanya akan dihasilkan melalui kegiatan investasi perusahaan.

Tujuan dilakukannya keputusan investasi adalah mendapat laba yang besar dengan risiko yang dapat dikelola dengan harapan dapat mengoptimalkan nilai perusahaan, yang berarti menaikkan kemakmuran pemegang saham (Afzal dan Rohman 2012). Dengan demikian semakin tinggi keuntungan perusahaan dari kegiatan investasi semakin tinggi nilai perusahaan, sehingga keputusan investasi menjadi pengaruh dalam pengembangan nilai perusahaan.

\subsubsection{Keputusan Pendanaan Berpengaruh Positif terhadap Nilai Perusahaan}

Hasil pengujian hipotesis kedua menunjukkan bahwa hipotesis kedua ditolak. Hasil pengujian menunjukkan bahwa keputusan pendanaan tidak memiliki pengaruh signifikan terhadap nilai perusahaan dengan nilai signifikansi 0,243 dimana nilai tersebut lebih besar dari 0,05 dan 0,1 $(\alpha=$ $5 \%$ dan 10\%). Hasil analisis tersebut tidak konsisten dengan hasil penelitian Darminto (2010), Wijaya et al. (2010), Ningsih dan Indarti (2011), Mandagi (2010), dan Afzal dan Rohman (2012) yang menyatakan bahwa keputusan pendanaan berpengaruh positif terhadap nilai perusahaan. Akan tetapi, hasil analisis ini konsisten dengan hasil penelitian Mandagi (2010) yang menyatakan bahwa keputusan pendanaan tidak memiliki pengaruh terhadap nilai perusahaan. Hasil tersebut dapat disebabkan oleh adanya kekhawatiran investor akan risiko kebangkrutan akibat dari penggunaan utang sebagai sumber pendanaan perusahaan. Semakin tinggi debt equity ratio perusahaan, semakin tinggi pula risiko perusahaan. Semakin tinggi hutang perusahaan, semakin besar pula kemungkinan terjadinya suatu kondisi dimana perusahaan tidak mampu membayar kewajibannya, sehingga risiko kebangkrutan akan semakin besar. Oleh karena itu, perusahaan harus berhati-hati dalam melakukan keputusan pendanaan. Perusahaan dapat menggunakan laba ditahan sebagai 
sumber pendanaan internal tambahannya. Penerbitan ekuitas baru dapat dijadikan alternatif terakhir karena dapat menyebabkan penurunan harga saham perusahaan.

Keputusan pendanaan yang dilakukan perusahaan dengan menggunakan pendanaan melalui ekuitas yang lebih banyak dari pada menggunakan pendanaan melalui hutang, maka laba yang diperoleh akan semakin besar. Penambahan hutang akan meningkatkan tingkat risiko atas arus pendapatan perusahaan, yang mana pendapatan dipengaruhi faktor eksternal, sedangkan hutang menimbulkan beban tetap tanpa memperdulikan besarnya pendapatan. Semakin besar hutang, semakin besar kemungkinan terjadinya perusahaan tidak mampu membayar kewajiban berupa bunga dan pokoknya. Menurut Endraswati (2009) cara untuk menurunkan risiko ini adalah mengurangi penggunaan hutang dalam perusahaan.

Darminto (2010) menyatakan bauran yang optimal akan menyumbangkan benefit dan cost, sehingga akan meminimalkan biaya modal dan meningkatkan nilai perusahaan. Pernyataan Darminto (2010) mendukung hasil penelitian ini, yaitu apabila kurangnya bauran yang optimal sehingga tidak menyumbangkan benefit dan cost yang menyebabkan keputusan pendanaan yang diputuskan tidak meningkatkan nilai perusahaan atau dalam kata lain keputusan pendanaan tidak berpengaruh terhadap pertumbuhan nilai perusahaan pada penelitian ini.

\subsubsection{Kepemilikan Manajerial Berpengaruh Positif terhadap Nilai Perusahaan}

Hasil pengujian hipotesis ketiga menunjukkan bahwa hipotesis ketiga diterima. Hasil pengujian menunjukkan bahwa kepemilikan manajerial memiliki pengaruh signifikan terhadap nilai perusahaan dengan nilai signifikansi 0,017 dimana nilai tersebut lebih kecil dari 0,05 dan 0,1 ( $\alpha=5 \%$ dan 10\%). Hasil analisis tersebut konsisten dengan hasil penelitian Wahyudi dan Pawestri (2006), Endraswati (2009), dan Sukirni (2012) yang menyatakan bahwa kepemilikan manajerial berpengaruh positif terhadap nilai perusahaan.

Kepemilikan manajemen dalam sebuah perusahaan akan menimbulkan dugaan yang menarik bahwa nilai perusahaan meningkat sebagai akibat kepemilikan manajemen yang meningkat. Kepemilikan oleh manajemen yang besar akan efektif memonitoring aktivitas perusahaan. Sebagai seorang manajer sekaligus pemegang saham perusahaan, manajer tidak ingin perusahaan mengalami kesulitan keuangan atau bahkan mengalami kebangkrutan. Sebagai manajer akan kehilangan insentif dan sebagai pemegang saham akan kehilangan return dari dana yang diinvestasikan. Siallagan dan Machfoedz (2006) menyatakan semakin besar kepemilikan manajemen dalam perusahaan maka manajemen akan cenderung untuk berusaha meningkatkan kinerjanya untuk kepentingan pemegang saham dan untuk kepentingannya sendiri. Dengan demikian, kepemilikan saham oleh manajerial diharapkan manajer akan bertindak sesuai dengan keinginan para principal karena manajer akan termotivasi untuk meningkatkan kinerja dan nantinya dapat meningkatkan nilai perusahaan. 


\subsubsection{Kepemilikan Institusional Berpengaruh Positif terhadap Nilai Perusahaan}

Hasil pengujian hipotesis keempat menunjukkan bahwa hipotesis keempat diterima. Hasil pengujian menunjukkan bahwa kepemilikan institusional memiliki pengaruh signifikan terhadap nilai perusahaan dengan nilai signifikansi 0,037 dimana nilai tersebut lebih kecil dari 0,05 dan 0,1 ( $\alpha=5 \%$ dan 10\%). Hasil analisis tersebut konsisten dengan hasil penelitian Sujoko dan Soebiantoro (2007), Endraswati (2009), dan Sukirni (2012) yang menyatakan bahwa kepemilikan institusional berpengaruh positif terhadap nilai perusahaan.

Keberadaan investor institusional dianggap mampu menjadi mekanisme monitoring yang efektif dalam setiap keputusan yang diambil oleh manajer. Hal ini disebabkan investor institusional terlibat dalam pengambilan yang strategis sehingga tidak mudah percaya terhadap tindakan manipulasi laba.

Kepemilikan institusional memiliki arti penting dalam memonitor manajemen. Adanya kepemilikan oleh institusional akan mendorong peningkatan pengawasan yang lebih optimal. Tingginya kepemilikan oleh institusi akan meningkatkan pengawasan terhadap perusahaan. Pengawasan yang tinggi ini akan meminimalisasi tingkat penyelewengan-penyelewengan yang dilakukan oleh pihak manajemen yang akan menurunkan nilai perusahaan. Semakin tinggi kepemilikan institusional maka akan mengurangi perilaku opportunistic manager yang diharapkan akan meningkatkan nilai perusahaan (Wahyudi dan Pawestri 2006). Pernyataan Wahyudi dan Pawestri (2006) mendukung hasil penelitian ini karena setiap saham yang dimiliki perusahaan manufaktur yang menjadi objek penelitian ini didominasi oleh kepemilikan institusional. Dengan demikian, semakin besar kepemilikan institusional maka semakin efisien pemanfaatan aktiva perusahaan dan diharapkan juga dapat bertindak sebagai pencegahan terhadap pemborosan dan manipulasi laba yang dilakukan oleh manajemen sehingga akan meningkatkan nilai perusahaan.

\subsubsection{Kebijakan Dividen Berpengaruh Positif Terhadap Nilai Perusahaan}

Hasil pengujian hipotesis kelima menunjukkan bahwa hipotesis kelima ditolak. Hasil pengujian menunjukkan bahwa kebijakan dividen tidak memiliki pengaruh signifikan terhadap nilai perusahaan dengan nilai signifikansi 0,293 dimana nilai tersebut lebih besar dari 0,05 dan 0,1 ( $\alpha=5 \%$ dan $10 \%$ ). Hasil analisis tersebut tidak konsisten dengan hasil penelitian Darminto (2010), dan Wijaya et al. (2010) yang menyatakan bahwa kebijakan dividen berpengaruh positif terhadap nilai perusahaan. Akan tetapi, hasil analisis ini konsisten dengan hasil penelitian Wahyudi dan Pawestri (2006), Endraswati (2009), Afzal dan Rohman (2012), dan Mandagi (2010) yang menyatakan bahwa kebijakan dividen tidak memiliki pengaruh terhadap nilai perusahaan.

Kebijakan dividen menentukan berapa banyak laba yang harus dibayar kepada pemegang saham dan berapa banyak yang harus ditanamkan kembali di dalam perusahaan. Pembayaran dividen dapat dilakukan setelah kewajiban terhadap pembayaran bunga dan cicilan hutang dipenuhi. Adanya kewajiban tersebut, akan membuat manajer berbuat lebih hati-hati. Hasil penelitian ini tidak mendukung hipotesis kebijakan dividen relevan yang menyatakan bahwa dividen yang tinggi dapat 
meningkatkan nilai perusahaan. Kebijakan dividen tidak berpengaruh secara signifikan terhadap nilai perusahaan disebabkan karena investor tidak membutuhkan dividen untuk mengkonversi saham mereka menjadi uang tunai, mereka tidak akan membayar harga yang lebih tinggi untuk perusahaan dengan pembayaran dividen yang lebih tinggi.

Selain itu kekhawatiran yang dihadapi oleh perusahaan dalam kebijakan dividen adalah seberapa banyak pendapatan yang bisa dibayarkan sebagai dividen dan seberapa banyak dapat dipertahankan, karena terkadang pembagian dividen bagi sebagian investor bukanlah sinyal positif. Investor menganggap manajer perusahaan tidak peka pada peluang investasi yang akan mendatangkan keuntungan namun lebih memilih membagikan dividen sehingga, nilai perusahaan dapat turun karena kurangnya keinginan pemegang saham untuk menanamkan modalnya pada perusahaan tersebut. Kemampuan perusahaan dalam membayarkan dividen dapat mencerminkan nilai perusahaan. Dengan kata lain, kebijakan dividen tidak akan berdampak pada nilai perusahaan jika perusahaan tidak memahami keinginan investor yang bisa berdampak pada penurunan nilai perusahaan.

\section{SIMPULAN DAN SARAN}

\subsection{Simpulan}

Berdasarkan pembahasan mengenai analisis pengembangan corporate value berdasarkan keputusan investasi dan pendanaan, struktur kepemilikan serta kebijakan dividen pada perusahaan manufaktur yang terdaftar di Bursa Efek Indonesia, maka disimpulkan beberapa hal sebagai berikut:

1. Hasil pengujian hipotesis pertama menunjukkan bahwa secara parsial variabel keputusan investasi memiliki pengaruh signifikan terhadap nilai perusahaan. Hal ini berarti semakin tinggi keuntungan perusahaan akan berpengaruh terhadap nilai perusahaan, dan berpengaruh juga terhadap kemakmuran yang akan diterima oleh pemilik perusahaan.

2. Hasil pengujian hipotesis kedua menunjukkan bahwa secara parsial variabel keputusan pendanaan tidak memiliki pengaruh signifikan terhadap nilai perusahaan. Perusahaan yang kurangnya bauran yang optimal, sehingga tidak menyumbangkan benefit dan cost dapat menyebabkan keputusan pendanaan yang diputuskan tidak meningkatkan nilai perusahaan. Hal ini berarti keputusan pendanaan yang tidak optimal atau tidak baik dan benar, tidak berpengaruh untuk meningkatkan nilai perusahaan yang baik juga.

3. Hasil pengujian hipotesis ketiga menunjukkan bahwa secara parsial variabel kepemilikan manajerial memiliki pengaruh signifikan terhadap nilai perusahaan. Hal ini berarti semakin besar kepemilikan manajerial, maka manajemen akan meningkatkan kinerja dan nantinya dapat meningkatkan nilai perusahaan.

4. Hasil pengujian hipotesis keempat menunjukkan bahwa secara parsial variabel kepemilikan institusional memiliki pengaruh signifikan terhadap nilai perusahaan. Hal ini berarti semakin 
tinggi kepemilikan institusional akan mengurangi perilaku opportunistic manager yang diharapkan akan meningkatkan nilai perusahaan.

5. Hasil pengujian hipotesis kelima menunjukkan bahwa secara parsial variabel kebijakan dividen tidak memiliki pengaruh signifikan terhadap nilai perusahaan. Kebijakan dividen tidak berpengaruh secara signifikan terhadap nilai perusahaan disebabkan karena terkadang pembagian dividen yang tinggi bagi sebagian investor bukanlah sinyal positif. Investor menganggap manajer perusahaan tidak peka pada peluang investasi yang akan mendatangkan keuntungan namun lebih memilih membagikan dividen. Hal ini berarti pembayaran dividen yang tinggi, maka tidak berpengaruh terhadap tingginya nilai perusahaan.

\subsection{Saran}

Berdasarkan hasil simpulan yang telah dikemukakan diatas, maka penulis memberikan beberapa saran yang mungkin dapat bermanfaat. Adapun saran-saran tersebut sebagai berikut:

1. Hasil penelitian menunjukkan bahwa keputusan investasi, kepemilikan manajerial dan kepemilikan institusional memiliki pengaruh signifikan terhadap nilai perusahaan. Keputusan investasi merupakan faktor penting dalam fungsi keuangan perusahaan. Oleh karena itu, keputusan perusahaan dalam melakukan kegiatan investasi harus hati-hati dan sangat diperhatikan agar hasil yang diharapkan dapat terwujud. Jika dikaitkan dengan kepemilikan manajerial, sebagai seorang manajer sekaligus pemegang saham perusahaan, manajer tidak ingin perusahaan mengalami kesulitan keuangan atau bahkan mengalami kebangkrutan. Sebagai manajer akan kehilangan insentif dan sebagai pemegang saham akan kehilangan return dari dana yang diinvestasikan. Begitu juga dengan kepemilikan institusional, semakin tinggi kepemilikan institusional maka akan mengurangi perilaku opportunistic manager yang diharapkan akan meningkatkan nilai perusahaan. Oleh karena itu, diharapkan kepemilikan manajerial dan selaku manajemen perusahaan dapat efektif setiap mengambil keputusan dan kepemilikan institusional akan selalu memonitoring setiap keputusan yang diambil manajemen untuk mendapatkan return yang besar dari saham yang mereka investasikan.

2. Hasil penelitian menunjukkan keputusan pendanaan dan kebijakan dividen tidak memiliki pengaruh signifikan terhadap nilai perusahaan. Berdasarkan teori yang telah ada sebelumnya, kedua variabel diatas adalah variabel yang cukup memungkinkan berkaitan dengan nilai perusahaan dan berpengaruh terhadap nilai perusahaan. Hal ini dimungkinkan karena variabel-variabel pendukung lainnya yang tidak menjadi variabel penelitian. Proksi yang digunakan dalam perhitungan juga mungkin kurang tepat sebagai data yang siap untuk diolah lebih lanjut.

3. Bagi peneliti selanjutnya agar dapat memperbesar jumlah sampel, menggunakan sektorsektor lain sebagai objek penelitian, dan menambahkan variabel-variabel lainnya. Dapat dilihat dari nilai adjusted $R^{2}$ hanya sebesar $13,4 \%$ yang berarti ada $86,6 \%$ merupakan 
pengaruh dari variabel-variable lainnya untuk menjelaskan nilai perusahaan, seperti umur perusahaan, ukuran perusahaan, Corporate Sosial Responsibility (CSR), dan struktur aset. Peneliti selanjutnya disarankan agar memperluas periode pengamatan agar lebih akurat dalam membandingkan hasil penelitian dari tahun ke tahun.

\section{DAFTAR PUSTAKA}

Afzal, A., dan A. Rohman. 2012. Pengaruh Keputusan Investasi, Keputusan Pendanaan, dan Kebijakan Dividen terhadap Nilai Perusahaan. Diponegoro Journal of Accounting 1 (2): 9.

Anthony, R., dan V. Govindarajan. 2005. Sistem Pengendalian Manajemen (Terjemahan). Jakarta: Salemba Empat.

Arieska, M., dan B. Gunawan. 2011. Pengaruh Aliran Kas Bebas dan Keputusan Pendanaan terhadap Nilai Pemegang Saham dengan Set Kesempatan Investasi dan Dividen sebagai Variabel Moderasi. Jurnal Akuntansi dan Keuangan 13 (1): 13-23.

Bestivano, W. 2013. Pengaruh Ukuran Perusahaan, Umur Perusahaan, Profitabilitas dan Leverage terhadap Perataan Laba pada Perusahaan yang Terdaftar di BEl. Skripsi. Padang: Fakultas Ekonomi Universitas Negeri Padang.

Bursa Efek Indonesia. 2014. Laporan Keuangan dan Laporan Tahunan Perusahaan 2013. http://www.idx.co.id (Diakses 11 November 2014).

Darminto. 2010. Pengaruh Faktor Eksternal dan Berbagai Keputusan Keuangan terhadap Nilai Perusahaan. Jurnal Aplikasi Manajemen 8 (1): 138-150.

Endraswati, H. 2009. Pengaruh Struktur Kepemilikan dan Kebijakan Dividen terhadap Nilai Perusahaan dengan Kebijakan Hutang sebagai Variabel Moderating pada Perusahaan di BEI. Tesis. Salatiga: STAIN.

Fenandar, G. I. 2012. Pengaruh Keputusan Investasi, Keputusan Pendanaan, dan Kebijakan Dividen terhadap Nilai Perusahaan. Skripsi. Semarang: Fakultas Ekonomika dan Bisnis Universitas Diponegoro.

Gayatri, N. L. P. R. G., dan I. K. Mustanda. 2013. Pengaruh Struktur Modal, Kebijakan Dividen dan Keputusan Investasi terhadap Nilai Perusahaan. E-Journal Manajemen Universitas Udayana 3 (6).

Hasnawati, S. 2005. Dampak Set Peluang Investasi terhadap Nilai Perusahaan Publik di Bursa Efek Jakarta. Jurnal Akuntansi dan Auditing Indonesia 9 (2): 117-126.

Hermuningsih, S., dan D. K. Wardani. 2009. Faktor-Faktor yang Mempengaruhi Nilai Perusahaan pada Perusahaan yang Terdaftar di Bursa Efek Malaysia dan Bursa Efek Indonesia. Jurnal Siasat Bisnis 13 (2): 173-183.

Hidayat, R. 2010. Keputusan Investasi dan Financial Constraints: Studi Empiris Pada Bursa Efek Indonesia. Buletin Ekonomi Moneter dan Perbankan 1 (1): 25-53.

Jensen, M. C., dan W. H. Meckling. 1976. Theory of the Firm: Managerial Behavior, Agency Cost, and Ownership Structure. Journal of Financial Economics 3 (4): 305-306.

Mandagi, S. E. A. 2010. Pengaruh Keputusan Keuangan terhadap Nilai Perusahaan Manufaktur yang Terdaftar di Bursa Efek Indonesia Periode 2008-2010. Jurnal Bisnis 28-32.

Ningsih, P.P., dan I. Indarti. (2011). Pengaruh Keputusan Investasi, Keputusan Pendanaan, dan Kebijakan Dividen terhadap Nilai Perusahaan. Jurnal Kajian Akuntansi dan Bisnis 1(1).

Novitasari, E. 2011. Implikasi Struktur Kepemilikan terhadap Nilai Perusahaan: Dengan Kebijakan Dividen sebagai Variabel Intervening pada Perusahaan Go Public di Bursa Efek Indonesia (BEI). Skripsi. Surabaya: Sekolah Tinggi Ekonomi Perbanas.

Permanasari, W.I. 2010. Pengaruh Kepemilikan Manajemen, Kepemilikan Institusional dan Corporate Social Responsibility terhadap Nilai Perusahaan. Skripsi. Semarang: Fakultas Ekonomi Universitas Diponegoro.

Siallagan, H, dan M. Machfoedz. 2006. Mekanisme Corporate Governance, Kualitas Laba dan Nilai Perusahaan. Makalah disajikan dalam Simposium Nasional Akuntansi IX. Padang.

Sudana, I. M. 2011. Manajemen Keuangan Perusahaan: Teori dan Praktik. Jakarta: Erlangga. 
Sujoko, dan U. Soebiantoro. 2007. Pengaruh Struktur Kepemilikan Saham, Leverage, Faktor Intern dan Faktor Ekstern terhadap Nilai Perusahaan. Jurnal Manajemen dan Kewirausahaan 9 (1): 41 48.

Sukirni, D. 2012. Kepemilikan Manajerial, Kepemilikan Institusional, Kebijakan Dividen, dan Kebijakan Hutang Analisis terhadap Nilai Perusahaan. Jurnal Akuntansi Fakultas Ekonomi.

Suranta, E., dan P. P. Merdistuti. 2003. Analisis Hubungan Struktur Kepemilikan Manajerial, Nilai Perusahaan dan Investasi dengan Model Persamaan Linear Simultan. Jurnal Riset Akuntansi Indonesia 6 (1): 54-68.

Tarjo. 2008. Pengaruh Konsentrasi Kepemilikan Institusional dan Leverage terhadap Manajemen Laba, Nilai Pemegang saham serta Cost of Equity Capital. Makalah disajikan dalam Simposium Nasioanal Akuntansi XI. Pontianak.

Wijaya, L. R.P., Bandi, dan A. Wibawa. 2010. Pengaruh Keputusan Investasi, Keputusan Pendanaan, dan Kebijakan Dividen Terhadap Nilai Perusahaan. Makalah disajikan dalam Simposium Nasional Akuntansi XIII. Purwokerto.

Wahyudi, U., dan H.P. Pawestri. 2006. Implikasi Struktur Kepemilikan Terhadap Nilai Perusahaan: Dengan Keputusan Keuangan Sebagai Variabel Intervening. Makalah Disajikan dalam Simposium Nasional Akuntansi IX. Padang. 